\title{
What are the current outcomes of advanced gastrointestinal stromal tumors: who are the long-term survivors treated initially with imatinib?
}

\author{
Piotr Rutkowski • Jolanta Andrzejuk • Elżbieta Bylina • Czesław Osuch • \\ Tomasz Świtaj • Anna Jerzak vel Dobosz • Urszula Grzesiakowska • \\ Monika Jurkowska • Agnieszka Woźniak • Janusz Limon • Maria Dębiec-Rychter • \\ Janusz A. Siedlecki
}

Received: 7 August 2013/Accepted: 31 October 2013/Published online: 12 November 2013

(C) The Author(s) 2013. This article is published with open access at Springerlink.com

\begin{abstract}
The introduction of imatinib to clinical practice revolutionized therapy of advanced gastrointestinal stromal tumors (GIST), but its long-term results have been only just collected. We have attempted to identify factors related to the long-term survival. We have analyzed the data of 430 inoperable/metastatic/recurrent GIST patients treated with imatinib in reference centers, assessed the factors influencing the long-term overall survival (OS), and compared the outcomes in three periods of initiation of imatinib therapy during one decade (2001-2003, 2004-2006, 2007-2010). During analyzed time periods, we have found decrease in median largest tumor size at the start of imatinib therapy: $90.5 \mathrm{~mm}(2001-2003)$ versus $74 \mathrm{~mm}$ (2004-2006) versus $58 \mathrm{~mm}(2007-2010) \quad(p=0.002)$. Median progression-free survival (PFS) on 1st line imatinib
\end{abstract}

P. Rutkowski $(\varangle) \cdot$ J. Andrzejuk · E. Bylina · T. Świtaj Department of Soft Tissue/Bone Sarcoma and Melanoma, Maria Sklodowska-Curie Memorial Cancer Center and Institute of Oncology, Roentgena 5, 02-781 Warsaw, Poland

e-mail: rutkowskip@coi.waw.pl

C. Osuch

Department of General Surgery, Jagiellonian University, Kopernika 40, 31-501 Cracow, Poland

\section{A. Jerzak vel Dobosz}

Department of Pathology, Maria Sklodowska-Curie Memorial Cancer Center and Institute of Oncology, Roentgena 5, 02-781 Warsaw, Poland

\section{U. Grzesiakowska}

Department of Radiology, Maria Sklodowska-Curie Memorial Cancer Center and Institute of Oncology, Roentgena 5,

02-781 Warsaw, Poland

M. Jurkowska

Department of Biochemistry and Molecular Biology, Institute of Rheumatology, Spartanska 1, 02-637 Warsaw, Poland was 37.5 months, without differences in PFS between three groups. Median OS was 5.8 years, 8-year OS rate was $43 \%$, and no difference in OS was demonstrated for patients treated in analyzed time periods. Independent good prognostic factors for longer OS were as follows: surgery of residual disease, initial WHO performance status 0/1, normal baseline albumin level, and the presence of exon 11 KIT mutations. Current median OS in advanced GIST reaches 6 years. The long-term survivors were characterized by smaller maximal tumors at imatinib start, better blood tests results, better performance status, and the surgical removal of residual disease. The latter might reduce the impact of tumor size and equalize the long-term results of therapy during last decade from introduction of imatinib. After introduction of subsequent lines of therapy (as

\author{
A. Woźniak \\ Laboratory of Experimental Oncology, Catholic University of \\ Leuven, Herestraat 49, Post 815, 3000 Louvain, Belgium \\ J. Limon \\ Department of Biology and Genetics, Medical University of \\ Gdansk, Debinki 1, 80-211 Gdańsk, Poland \\ M. Dębiec-Rychter \\ Center for Human Genetics, Catholic University of Leuven, \\ Herestraat 49, Post 815, 3000 Louvain, Belgium
}

J. A. Siedlecki

Department of Molecular Biology, Maria Sklodowska-Curie Memorial Cancer Center and Institute of Oncology,

Roentgena 5, 02-781 Warsaw, Poland 
sunitinib), the effect of primary mutational status on the long-term OS is also less visible.

Keywords Gastrointestinal stromal tumor . Imatinib · Prognosis · Predictive factors · Long-term survivors

\section{Introduction}

The introduction of imatinib to therapy of advanced gastrointestinal stromal tumors (GIST) has dramatically improved the outcomes of these tumors [1, 2]. Imatinib as tyrosine kinase inhibitor inhibiting KIT/PDGFRA (plateletderived growth factor receptor alpha) and their downstream signaling cascade in GIST cells is currently standard of care in the first-line therapy of inoperable and/or metastatic tumors [3], and became the model of targeted therapy of solid tumors. Its efficacy has been also proven recently in adjuvant setting after resection of primary high-risk tumors $[4,5]$. However, a majority of patients eventually develop clinical resistance to imatinib. Over the last few years, major progress has been made in elucidating the mechanism of disease progression and resistance to imatinib such as secondary mutations in KIT and/or PDGFRA kinase domains. Currently, the sole-approved second-line drug is sunitinib - a multi-targeted agent [6]. Moreover, a number of new generation tyrosine kinase inhibitors (as regorafenib, registered recently in USA), alone or in combination, are being evaluated at present alongside treatment options alternative to inhibiting the KIT signaling pathway [7].

There are limited data regarding the long-term outcomes of metastatic GIST outside the clinical trials in routine practice. The aim of this large contemporary series of inoperable/metastatic GIST was to identify factors related to progression-free and overall survival (OS) of patients starting imatinib therapy as well as to attempt to identify the factors related to subgroup of patients with the longterm survival.

\section{Patients and methods}

Patients

In this observational study, we analyzed collected prospectively data of 430 consecutive patients treated initially with imatinib mesylate (according to approved registration) due to inoperable and/or metastatic histologically confirmed, CD117-positive GIST, who were treated or referred to tertiary sarcoma center within framework of the Polish Clinical GIST Registry between September 1, 2001 and December 31, 2010. Each patient provided informed consent for the study. The study has been approved by the local Bio-Ethics Committee according to Good Clinical Practice Guidelines. Patients did not undergo any further selection. The distribution of clinical and pathological data of patients included in the study is listed in Table 1 . There were 226 male and 204 female patients, with median age at the start of imatinib therapy 58 years (range 15-89).

All but eight patients (who started imatinib therapy from $800 \mathrm{mg} /$ day) were treated with imatinib in initial dose of $400 \mathrm{mg}$ daily. All patients were followed carefully with median follow-up time for survivors of 51 months. The objective response of GIST to imatinib therapy was evaluated with serial $\mathrm{CT}$ examinations (performed every 2-3 months), according to Response Evaluation Criteria in Solid Tumors (RECIST) version 1.0 [8]. In doubtful cases of progressive disease, additional Choi's criteria were applied [9]. In the case of progression or unacceptable toxicity (three cases), patients were treated with imatinib at the higher doses (600-800 mg daily) or the therapy was immediately changed to sunitinib. One hundred and eightyeight progressing patients were thereafter treated with sunitinib (since 2005). Subsequently, patients were treated according to decision of treating physician with either best supportive care, experimental therapy (nilotinib or regorafenib), off-label use of sorafenib, reintroduction of imatinib, or chemotherapy.

Multidisciplinary team evaluated possibility of surgical treatment of residual lesions (liver and/or intraperitoneal metastases), which had been estimated as resectable after maximal response to imatinib (as described previously) [10].

Genomic screening was performed for the presence of the KIT (exons 9, 11, 13, and 17) or PDGFRA (exons 12, 14 , and 18) genes mutation in randomly selected 220 cases, based on DNA isolated from paraffin-embedded or freshfrozen imatinib-naive tumor tissues, as previously described [11].

\section{Statistical analyses}

All statistical analyses were performed using R 2.10.1 statistical program. ${ }^{1}$ For the survival analysis, the KaplanMeier estimator was used with the log-rank tests for bivariate comparisons. The primary objective of the study was to assess the OS of advanced GIST treated initially with imatinib as well as to identify the factors related to longer OS time. The secondary objectives were to estimate progression-free survival (PFS) on imatinib therapy and to describe the factors related to improved PFS time. OS time was calculated from the date of the start of imatinib treatment to the date of the most recent follow-up or death.

\footnotetext{
${ }^{1}$ R Development Core Team; http://www.R-project.org.
} 
Table 1 Characteristics of 430 patients treated initially with imatinib due to advanced GIST

\begin{tabular}{|c|c|}
\hline Clinicopathological features & No. of patients \\
\hline Total number of patients & $430(100 \%)$ \\
\hline \multicolumn{2}{|l|}{ Age (years) at the start of imatinib therapy } \\
\hline Median (range) mean & $58(15-89) 5$ \\
\hline$\leq 40$ & $42(9.8 \%)$ \\
\hline$>40$ & $388(90.2 \%)$ \\
\hline \multicolumn{2}{|l|}{ Gender } \\
\hline Female & $204(47.4 \%)$ \\
\hline Male & $226(52.6 \%)$ \\
\hline \multicolumn{2}{|l|}{ The period of initiation of imatinib therapy (years) } \\
\hline $2001-2003$ & $100(23.3 \%)$ \\
\hline 2004-2006 & $166(38.6 \%)$ \\
\hline $2007-2010$ & $164(38.1 \%)$ \\
\hline \multicolumn{2}{|l|}{ Primary tumor site } \\
\hline Stomach & $151(35.1 \%)$ \\
\hline Duodenum & $23(5.4 \%)$ \\
\hline Small bowel & $179(41.6 \%)$ \\
\hline Large bowel/rectum & $34(7.9 \%)$ \\
\hline $\begin{array}{l}\text { Other or intraperitoneally with unknown primary } \\
\text { origin }\end{array}$ & $43(10.0 \%)$ \\
\hline \multicolumn{2}{|l|}{ The maximal diameter of the largest tumor ( $\mathrm{mm}$ ) } \\
\hline Median (range) & $73(10-400)$ \\
\hline$\leq 50$ & $108(25.1 \%)$ \\
\hline$>50-100$ & $105(24.4 \%)$ \\
\hline$>100$ & $118(27.4 \%)$ \\
\hline Data not available & $99(23.0 \%)$ \\
\hline \multicolumn{2}{|l|}{ Resection of residual disease during imatinib therapy } \\
\hline Yes & $94(21.9 \%)$ \\
\hline No & $336(78.9 \%)$ \\
\hline \multicolumn{2}{|l|}{ Presence of liver metastases at imatinib start } \\
\hline Yes & $220(51 \%)$ \\
\hline No & $210(49 \%)$ \\
\hline \multicolumn{2}{|l|}{ Tumor genotype $^{a}$} \\
\hline KIT exon 11 & $139(63.2 \%)$ \\
\hline KIT exon 9 & $29(13.1 \%)$ \\
\hline Wild type & $34(15.5 \%)$ \\
\hline PDGFRA exon $18 \mathrm{D} 842 \mathrm{~V}$ & $9(4.1 \%)$ \\
\hline Other & $9(4.1 \%)$ \\
\hline \multicolumn{2}{|l|}{ Baseline albumin level } \\
\hline Low $(<35 \mathrm{~g} / \mathrm{l})$ & $58(13.5 \%)$ \\
\hline Normal (>35 g/l) & $230(53.5 \%)$ \\
\hline Data not available & $142(33.0 \%)$ \\
\hline \multicolumn{2}{|l|}{ Baseline hemoglobin level } \\
\hline Low $(<11 \mathrm{~g} / 100 \mathrm{ml})$ & $65(15.1 \%)$ \\
\hline Normal ( $\geq 11 \mathrm{~g} / 100 \mathrm{ml})$ & $278(64.7 \%)$ \\
\hline Data not available & $87(20.2 \%)$ \\
\hline \multicolumn{2}{|l|}{ Baseline neutrophils count } \\
\hline $\operatorname{High}\left(>5 \times 10^{9} / 1\right)$ & $72(16.7 \%)$ \\
\hline Normal $\left(<5 \times 10^{9} / 1\right)$ & $262(60.9 \%)$ \\
\hline
\end{tabular}

Table 1 continued

\begin{tabular}{lc}
\hline Clinicopathological features & No. of patients \\
\hline Data not available & $96(22.3 \%)$ \\
Performance status (WHO score) & \\
Poor $\geq 2$ & $75(17.5 \%)$ \\
Good $<2$ & $272(63.2 \%)$ \\
Data not available & $83(19.3 \%)$ \\
\hline
\end{tabular}

${ }^{a}$ Mutational status was evaluated in 220 cases

PFS time was calculated from the date of the start of imatinib treatment to the date of the most recent follow-up, or progression or death due to the disease. The survival was assessed with respect to the following variables: demographic data (age at the start of imatinib therapy $\leq 40$ or $>40$ years; gender), the period of initiation of imatinib therapy (2001-2003 vs. 2004-206 vs. 2007-2010), primary tumor genotype (KIT exon 11, KIT exon 9, PDGFRA exon $18 \mathrm{D} 842 \mathrm{~V}$ mutations, wild type, and other cases), the maximal diameter of the largest tumor at imatinib start, the presence versus absence of liver metastases, primary tumor site (gastric vs. duodenum vs. small bowel-ileum or jejunum vs. large bowel vs. other or intraperitoneally with unknown primary origin), baseline (1-7 days before start of imatinib therapy) albumin level (low $<35 \mathrm{~g} / \mathrm{l}$ vs. normal $>35 \mathrm{~g} / \mathrm{l}$ ), baseline (1-7 days before start of imatinib therapy) hemoglobin level (low $<11 \mathrm{~g} / 100 \mathrm{ml}$ or normal $\geq 11 \mathrm{~g} / 100 \mathrm{ml}$ ), baseline (1-7 days before start of imatinib therapy) neutrophils count (high $>5 \times 10^{9} / 1$ vs. normal $\left.<5 \times 10^{9} / 1\right)$, baseline (1-7 days before start of imatinib therapy) performance status according to World Health Organization (WHO) (good: $0-1$ vs. poor $\geq 2$ ), and the fact of resection of GIST residual disease during imatinib therapy. In multivariate analysis of the factors associated with PFS, we used Cox proportional hazards models, applying the stepwise model building procedure that included all covariates significant at $20 \%$ level in bivariate analysis. The best model was based on Akaike's criterion. The differences were considered statistically significant if the $p$ values were $<0.05$.

\section{Results}

Clinicopathological and mutational data

During analyzed time periods, we have found decrease in median largest tumor size at the start of imatinib therapy: $90.5 \mathrm{~mm}$ (2001-2003) versus $74 \mathrm{~mm}$ (2004-2006) versus $58 \mathrm{~mm}(2007-2010)(p=0.002)$.

The distribution of patients according to the tumor mutational status is shown in Table 1 . In total, $85 \%$ of 
cases revealed a $K I T$ or PDGFRA mutation (63\%-exon $11 K I T, 13 \%$-exon $9 \mathrm{KIT}, 4.1 \%$-exon 18 PDGFRA $\mathrm{D} 842 \mathrm{~V}$, and $4.1 \%$-other types of mutation).

Progression-free survival on imatinib therapy

Progression of disease during imatinib therapy was observed in 246 cases $(57 \%)$. Median PFS was 37.5 months, and estimated 5- and 8-year PFS rates were 37.0 and $27 \%$, respectively.

We have not observed significant differences in PFS between three analyzed periods of time (Fig. 1).

In univariate analysis, the following factors correlated with shorter PFS (Table 2a): lack of resection of residual disease during imatinib therapy, primary tumor located in duodenum or intraperitoneally with unknown primary origin, the maximal tumor diameter of the largest tumor $>100 \mathrm{~mm}$, tumor mutation other than KIT exon 11, the younger age, low baseline albumin level, high baseline neutrophils count, low baseline hemoglobin level, and poor performance status.

In the multivariate analysis (final Cox model), we identified the following independent predictive factors, which correlated with poorer PFS (Table 3a): worse baseline WHO performance status, high baseline neutrocyte count, low baseline hemoglobin level, younger age, the lack of resection of residual disease, primary tumor site, and tumor mutation other than KIT exon 11.

\section{Overall survival}

At the time of analysis, 241 (56\%) patients were alive. Median OS was 37.5 months, and estimated 5- and 8-year PFS rates were 57 and $47 \%$, respectively (Fig. 2a).

We have not observed significant differences in OS between three analyzed periods of time (data not shown).

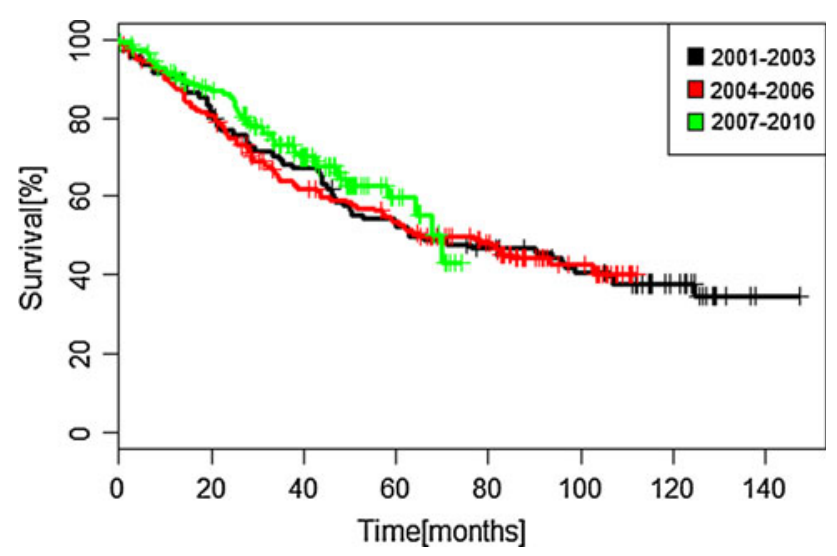

Fig. 1 Progression-free survival according to periods of time of initiation of imatinib therapy
The following factors significantly influenced OS in bivariate analysis (Table $2 \mathrm{~b}$ ): poor baseline WHO performance status $\geq 2$, baseline high neutrocyte count, baseline low albumin level, low baseline hemoglobin level, the maximal diameter of the largest tumor $>10 \mathrm{~cm}$ (Fig. 2b), and the lack of resection of residual disease during imatinib therapy (Fig. 2c). Patients with primary tumors carrying mutation D842V in exon 18 PDGFRA had substantially shorter OS reaching median OS only 15.5 months (Fig. 2d).

The following factors were found to be independent predictors of better OS according to multivariate analysis (Table 3b): good baseline WHO performance status, normal baseline albumin level, the resection of residual disease during imatinib therapy, the presence of exon 11 KIT mutations, and (with borderline significance) the maximal tumor diameter of the largest tumor $>10 \mathrm{~cm}$.

\section{Discussion}

Our data comprise the largest series of advanced GIST patients treated in routine practice and were collected prospectively in tumor-type-specific national registry with the long follow-up. Several conducted clinical trials confirmed high efficacy of imatinib in the treatment of inoperable/metastatic GIST [1, 2, 12, 13] as compared to historical clinical data with median survival of patients being 10-19 months [3, 14], with the current survival being strikingly superior [15]. The median OS reported until now in few studies reached only from 4.0 to 6.4 years [12, 13, 16-21]. Our data confirm this superior survival. Moreover, although the spectacular response to imatinib therapy is time-limited and followed by the development of secondary resistance (after initial stabilization or response) in the majority of patients, still $1 / 4$ of patients have not been progressing at 8 years of therapy with imatinib. The current PFS in our series on first-line therapy with imatinib is approximately 3 years, what is almost the same as in the recent Taiwanese one-institution study [20], and it did not improve significantly over decade from the turning point of introduction of imatinib to clinical practice. However, we have found systematically decrease in maximal tumor burden during this period of time, what is probably related to better follow-up of patients after resection of primary tumor and earlier detection of recurrent disease. The cutoff value for tumor bulk which had significantly inferior impact on PFS and OS was $10 \mathrm{~cm}$ in our series defined as the single largest size of measurable lesions. It confirms the previous data that largest tumor may be related to higher likelihood of development of resistant clones and secondary mutations [13, 20, 22-25], and it underlines the utility of tumor bulk assessment by the single largest lesion. 


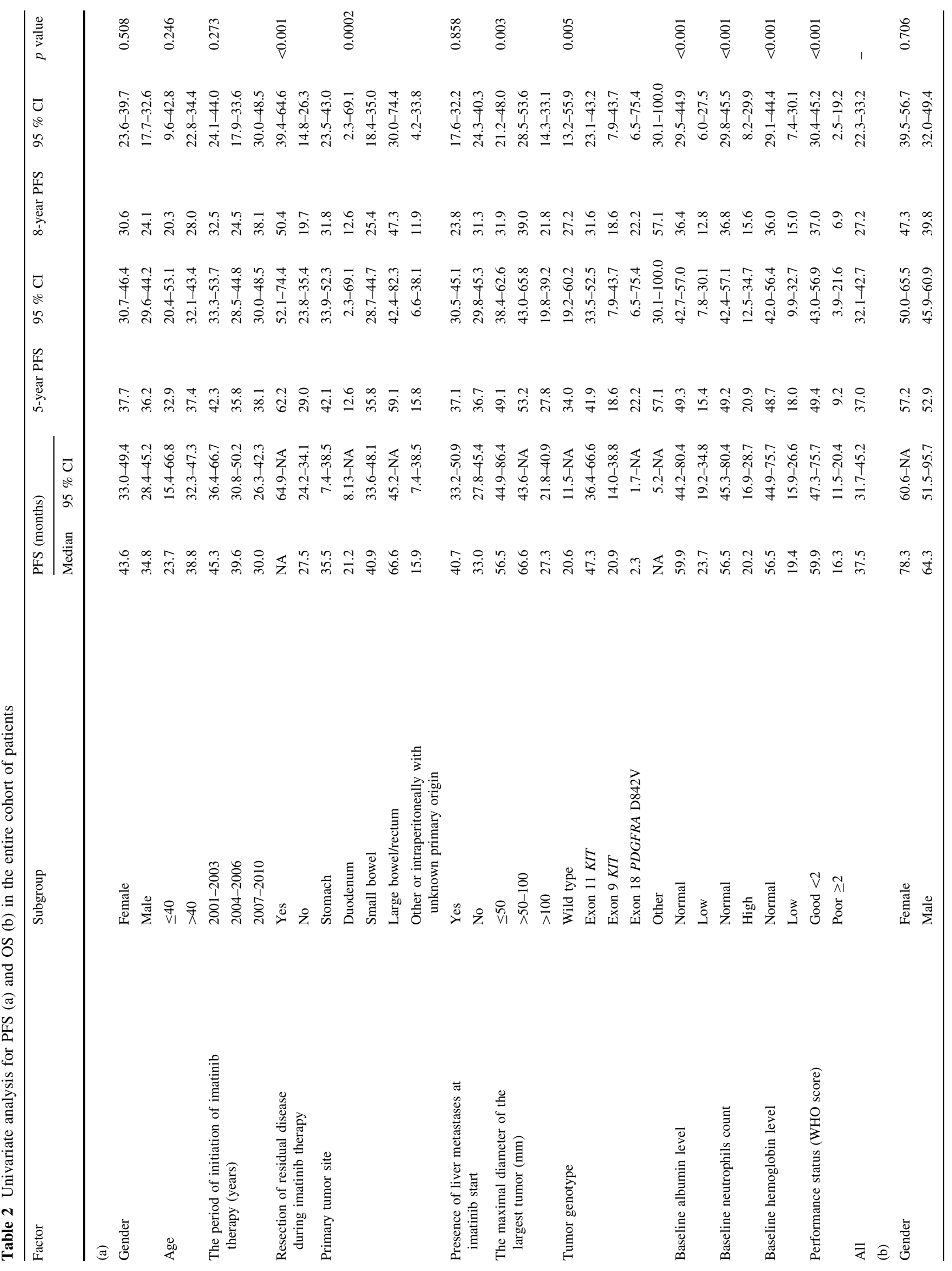




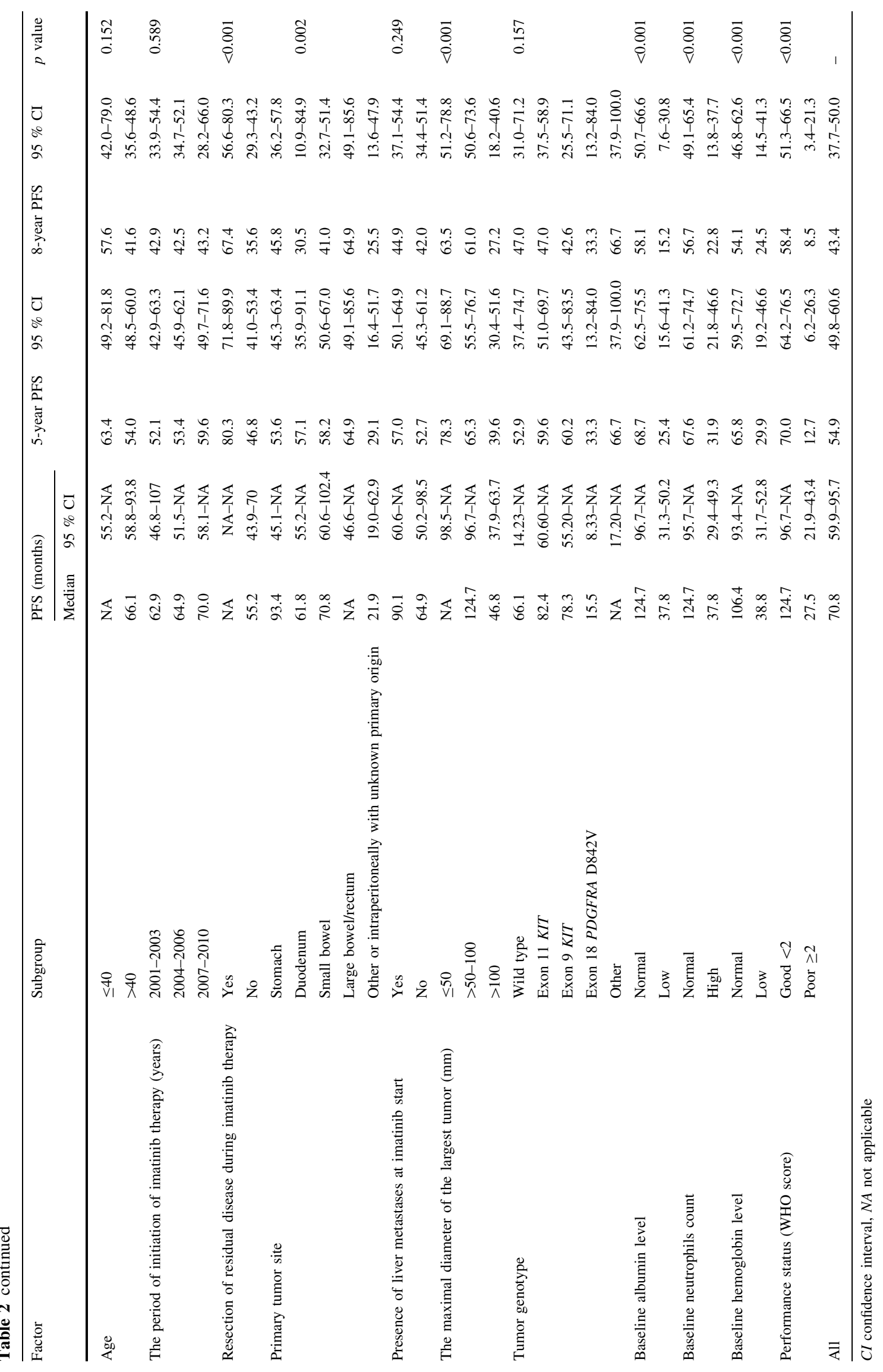


Table 3 Multivariate analysis of prognostic factors for PFS (a) and OS (b)

\begin{tabular}{|c|c|c|c|c|}
\hline Factor & Subgroup & HR & $95 \% \mathrm{CI}$ & $p$ value \\
\hline \multicolumn{5}{|l|}{ (a) } \\
\hline \multirow[t]{2}{*}{ Age } & $>40$ & 1.00 & & \\
\hline & $\leq 40$ & 1.802 & $1.1875-2.7347$ & 0.005 \\
\hline \multirow{2}{*}{$\begin{array}{l}\text { Resection of residual disease } \\
\text { during imatinib therapy }\end{array}$} & Yes & 1.00 & & \\
\hline & No & 0.3539 & $0.2420-0.5175$ & $<0.001$ \\
\hline \multirow[t]{5}{*}{ Primary tumor site } & Duodenum & 1.00 & & \\
\hline & Small bowel & 0.7208 & $0.4097-1.2682$ & 0.256 \\
\hline & Large bowel/rectum & 0.3959 & $0.1793-0.8741$ & 0.022 \\
\hline & Stomach & 0.4711 & $0.2576-0.8613$ & 0.014 \\
\hline & $\begin{array}{l}\text { Other or intraperitoneally with } \\
\text { unknown primary origin }\end{array}$ & 1.315 & $0.6809-2.5401$ & 0.415 \\
\hline \multirow[t]{5}{*}{ Tumor genotype } & Wild type & 1.00 & & \\
\hline & Exon $11 K I T$ & 0.5897 & $0.3458-1.0055$ & 0.052 \\
\hline & Exon $9 K I T$ & 1.2 & $0.6183-2.3292$ & 0.589 \\
\hline & Exon $18 P D G F R A$ D842V & 4.102 & $1.6520-10.1851$ & 0.002 \\
\hline & Other & 0.9746 & $0.2781-3.4154$ & 0.968 \\
\hline \multirow[t]{2}{*}{ Baseline neutrophils count } & Normal & 1.00 & & \\
\hline & High & 1.72 & $1.1724-2.5248$ & 0.006 \\
\hline \multirow[t]{2}{*}{ Baseline hemoglobin level } & Normal & 1.00 & & \\
\hline & Low & 1.592 & $1.0396-2.4385$ & 0.032 \\
\hline \multirow[t]{2}{*}{ Performance status (WHO score) } & Good $<2$ & 1.00 & & \\
\hline & Poor $\geq 2$ & 2.79 & $1.8647-4.1755$ & $<0.001$ \\
\hline \multicolumn{5}{|l|}{ (b) } \\
\hline \multirow{2}{*}{$\begin{array}{l}\text { Resection of residual disease } \\
\text { during imatinib therapy }\end{array}$} & Yes & 1.00 & & \\
\hline & No & 0.3179 & $0.20001-0.5052$ & $<0.001$ \\
\hline \multirow[t]{5}{*}{ Primary tumor site } & Duodenum & 1.00 & & \\
\hline & Small bowel & 1.2 & $0.59257-2.4317$ & 0.612 \\
\hline & Large bowel/rectum & 0.9214 & $0.36381-2.3337$ & 0.863 \\
\hline & Stomach & 0.8693 & $0.41325-1.8285$ & 0.712 \\
\hline & $\begin{array}{l}\text { Other or intraperitoneally with } \\
\text { unknown primary origin }\end{array}$ & 2.437 & $1.08447-5.4745$ & 0.031 \\
\hline \multirow{2}{*}{$\begin{array}{l}\text { Presence of liver metastases at } \\
\text { imatinib start }\end{array}$} & Yes & 1.00 & & \\
\hline & No & 1.387 & $1.01151-1.9029$ & 0.042 \\
\hline \multirow{3}{*}{$\begin{array}{l}\text { The maximal diameter of the } \\
\text { largest tumor }(\mathrm{mm})\end{array}$} & $\leq 50$ & 1.00 & & \\
\hline & $>50-100$ & 1.04 & $0.60162-1.7980$ & 0.888 \\
\hline & $>100$ & 1.636 & $0.97002-2.7583$ & 0.065 \\
\hline \multirow[t]{5}{*}{ Tumor genotype } & Wild type & 1.00 & & \\
\hline & Exon $11 K I T$ & 0.4466 & $0.24163-0.8254$ & 0.01 \\
\hline & Exon $9 K I T$ & 0.6156 & $0.28451-1.3318$ & 0.218 \\
\hline & Exon 18 PDGFRA D842V & 3.049 & $1.142-8.1414$ & 0.026 \\
\hline & Other & 0.4076 & $0.09017-1.8429$ & 0.244 \\
\hline \multirow[t]{2}{*}{ Baseline albumin level } & Normal & 1.00 & & \\
\hline & Low & 2.415 & $1.48174-3.9363$ & 0.0004 \\
\hline \multirow[t]{2}{*}{ Baseline hemoglobin level } & Normal & 1.00 & & \\
\hline & Low & 1.007 & $0.60318-1.6801$ & 0.979 \\
\hline \multirow[t]{2}{*}{ Performance status (WHO score) } & Good $<2$ & 1.00 & & \\
\hline & Poor $\geq 2$ & 2.427 & $1.53092-3.8491$ & 0.0002 \\
\hline
\end{tabular}

$H R$ hazard ratio, $C I$ confidence interval 

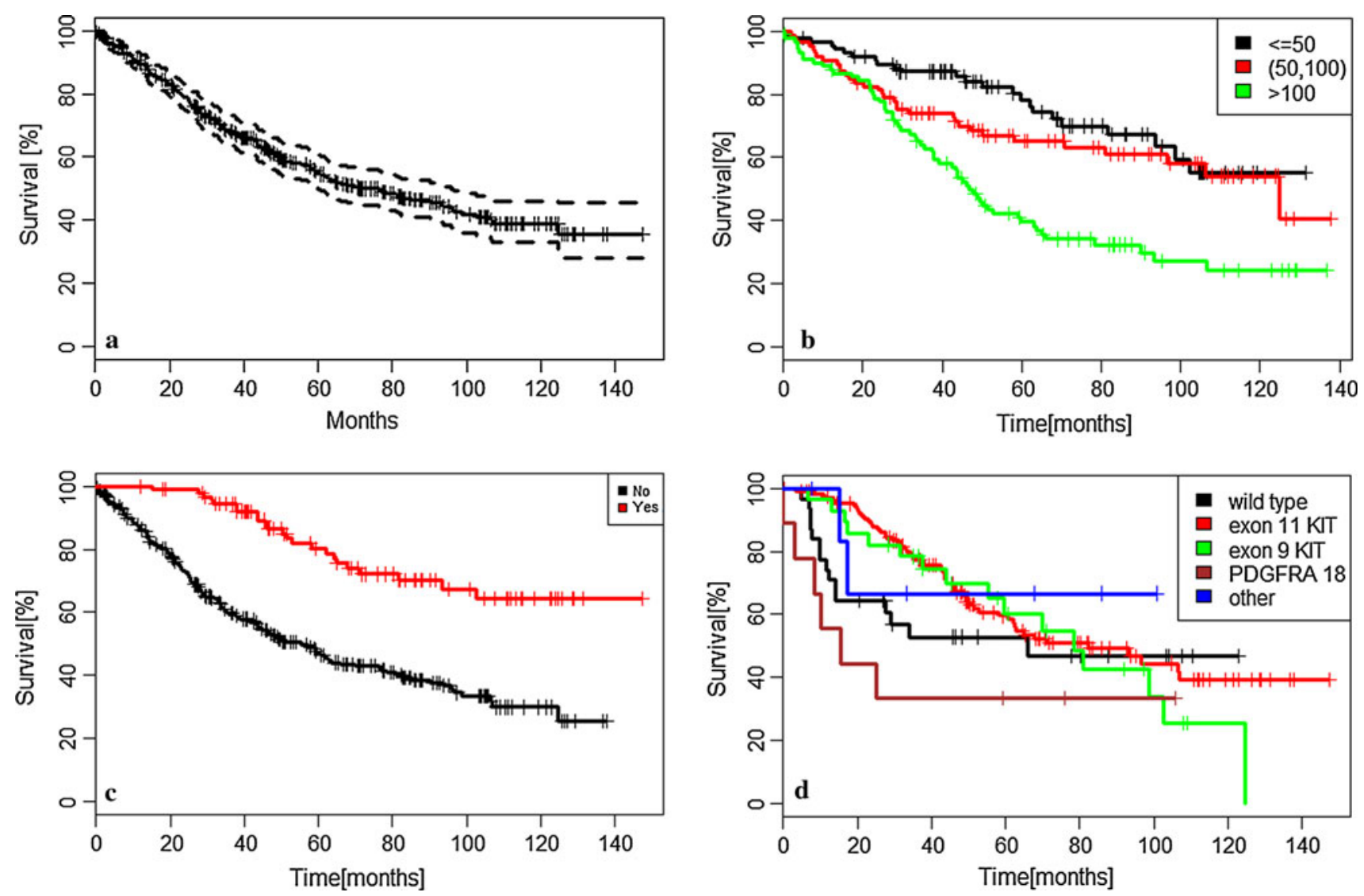

Fig. 2 Overall survival: in the entire group of patients (a); according to maximal diameter of tumor at start of imatinib therapy in mm (b); according to the lack of resection of residual disease during imatinib therapy (c); and according to initial mutational status (d)

We have previously identified some predictive factors for the benefit of imatinib therapy in terms of inhibition of disease progression in advanced GIST [26]. Also, van Glabbeke and co-authors [27] had reported data on distinctive predictive clinicopathological factors for initial and late resistance to imatinib in advanced GISTs, but this analysis did not include the genotyping of the tumor as well as the strategy of removal of residual disease during therapy with tyrosine kinase inhibitors. Currently, we have expanded the variables predictive for the long-term outcomes and survival of inoperable and/or metastatic GISTs treated initially with imatinib. Based on these results of univariate and multivariate analyses, we can identify the patients' factors which are related to benefits of longer survival: initial better performance status and laboratory test results (especially normal albumin level), primary tumor genotype (exon 11 KIT mutants and genotype other than exon 18 PDGFRA D842V), the smaller maximal size of the largest tumor, and resection of residual disease during imatinib therapy. These factors may account for the basis for development of the nomogram for PFS and OS [28]. Laboratory factors as high granulocyte count, low hemoglobin level, or low albumin level together with poor general performance status were previously implied as predictive factors for resistance to imatinib therapy $[12,13$, 17, 18, 23, 26, 27]. Consistently with the results of present series, these factors can be related to generally more advanced and aggressive tumors, with higher inflammatory component influencing pharmacokinetics of the drug [13, 17, 27, 29, 30].

In patients with available data on tumor genotype, we found consistently with results already reported [12, 3134] that the mutational status had significant impact on prognosis, with the best results for KIT exon 11 mutants in terms of PFS and OS. For OS, the effect of presence of KIT exon 11 as compared to KIT exon 9 mutations was less evident, which may be related to the impact of subsequent lines of therapy (mainly with sunitinib, which is more active for KIT exon 9 mutants [35]. Notably, according to Blanke et al. [13], the effect of exon 11 KIT mutations on OS mainly resulted from their strong effect during the first 30 months of treatment. We could not analyze the influence of higher dose of imatinib on PFS in subgroup of patients with KIT exon 9 mutations because all but eight patients started therapy from registered dose of $400 \mathrm{mg}$. The available data (from EORTC-ISG-AGITG 62005 trial 
and meta-analysis with S0033) have shown that the response of patients with exon 9 KIT mutations depends on the dose of the drug and that these patients under higher does (800 mg daily) of imatinib demonstrate significant improvement of PFS as compared to a standard dose of $400 \mathrm{mg}$ daily (without impact on OS) [17, 36]. Furthermore, although the presence of PDGFRA D842V mutation is related to more indolent disease in primary resectable GIST [37], it is poor prognostic factor in advanced disease, as this mutation is insensitive to commonly used tyrosine kinase inhibitors (including imatinib and sunitinib) [33, 38] and is responsible for primary resistance to imatinib.

Surgery of residual disease in situation of absence of disease progression was found as the most independent prognostic factor for better outcomes in advanced GIST. Some studies have already reported favorable outcomes of surgery in responding patients [10, 39-42]. The present series demonstrate clear improvement in the long-term term survival in the group of patients operated after response to imatinib therapy (median PFS and OS were not reached). Although we cannot exclude selection bias as the role of surgery in metastatic GIST has never been confirmed in prospective study (as the initiated studies failed because of slow recruitment) [43], we still believe in real impact of this strategy on natural course of the disease. It can theoretically prolong durable remission, because the excision of the tumor is performed before the development of imatinib resistance, and thus, the risk of resistant clone selection is reduced. We have rather liberally used surgical removal of residual disease after individual decision made on multidisciplinary tumor board, as more than $20 \%$ patients responding to systemic therapy underwent surgery following imatinib therapy, what might reduce the impact of initial tumor size at advanced setting.

Although imatinib is the most important therapy in GIST, predominantly influencing survival in advanced disease, the difference between median PFS and OS on initial therapy with imatinib in our study is more than 2.5 years. There are several reasons for these results, suggesting relative efficacy of salvage therapy after imatinib failure. Multidisciplinary approach after progression on initial dose of imatinib includes increase of the dose of imatinib to $800 \mathrm{mg}$ daily [44], surgical resection, or ablation of focally progressive disease [10, 39, 42], using therapy with alternative receptor tyrosine kinase inhibitors (as second-line registered multi-targeted tyrosine inhibitor sunitinib, or further line therapy with sorafenib or regorafenib, which recently has been approved in USA) [7, 45]. We have recently analyzed the results of sunitinib therapy in series of 137 patients after failure of imatinib therapy and demonstrated survival exceeding 1.5 years from start of sunitinib [36], as well as we have also proven that contrary to imatinib, tumors initially (pre-imatinib treatment) bearing KIT exon 9 mutation or with wild-type genotype have a higher chance to respond to sunitinib. We also actively used therapy with alternative tyrosine kinase inhibitors after progression on imatinib and sunitinib (not only best supportive care), which also may be related to better OS observed in our study [46] and lack of differences between different periods of treatment.

To summarize, the current median survival in advanced GIST reaches 6 years. The long-term survivors (with OS exceeding 5 years) were characterized by smaller maximal tumors at start of imatinib therapy, better laboratory tests results, better performance status, and more commonly use of surgical removal of residual disease. The latter might reduce the impact of tumor size and equalize the long-term results of therapy during last decade from the introduction of imatinib. In addition, after introduction of subsequent lines of therapy, the effect of primary mutational status (with exception of PDGFRA-D842V) on long-term OS is less visible.

Acknowledgments We thank Daniel Rabczenko for statistical assistance.

Conflict of interest P. Rutkowski, C. Osuch and A. Wozniak have received honoraria and travel grants form. Novartis, P. Rutkowski, and M. Debiec-Rychter served in advisory board for Novartis; P. Rutkowski and J. Andrzejuk have received honoraria and travel grants from Pfizer.

Open Access This article is distributed under the terms of the Creative Commons Attribution License which permits any use, distribution, and reproduction in any medium, provided the original author(s) and the source are credited.

\section{References}

1. Demetri GD, von Mehren M, Blanke CD, Van den Abbeele AD, Eisenberg B, Roberts PJ, Heinrich MC, Tuveson DA, Singer S, Janicek M, Fletcher JA, Silverman SG, Silberman SL, Capdeville R, Kiese B, Peng B, Dimitrijevic S, Druker BJ, Corless C, Fletcher CD, Joensuu H. Efficacy and safety of imatinib mesylate in advanced gastrointestinal stromal tumors. $\mathrm{N}$ Engl $\mathrm{J}$ Med. 2002;347:472-80.

2. Verweij J, Casali PG, Zalcberg J, LeCesne A, Reichardt P, Blay JY, Issels R, van Oosterom A, Hogendoorn PC, Van Glabbeke M, Bertulli R, Judson I. Progression-free survival in gastrointestinal stromal tumours with high-dose imatinib: randomised trial. Lancet. 2004;364:1127-34.

3. Rutkowski P, Symonides M, Zdzienicki M, Siedlecki JA. Developments in targeted therapy of advanced gastrointestinal stromal tumors. Recent Pat Anticancer Drug Discov. 2008; 3(2):88-99.

4. DeMatteo R, Ballman KV, Antonescu CR, Maki RG, Pisters PW, Demetri GD, Blackstein ME, Blanke CD, von Mehren M, Brennan MF, Patel S, McCarter MD, Polikoff JA, Tan BR, Owzar K, ACOSOG Intergroup Adjuvant GIST Study Team. Adjuvant imatinib mesylate after resection of localised, primary gastrointestinal stromal tumour: a randomised, double-blind, placebocontrolled trial. Lancet. 2009;373:1079-104. 
5. Joensuu H, Eriksson M, Sundby Hall K, Hartmann JT, Pink D, Schütte J, Ramadori G, Hohenberger P, Duyster J, Al-Batran SE, Schlemmer M, Bauer S, Wardelmann E, Sarlomo-Rikala M, Nilsson B, Sihto H, Monge OR, Bono P, Kallio R, Vehtari A, Leinonen $\mathrm{M}$, Alvegård $\mathrm{T}$, Reichardt $\mathrm{P}$. One vs three years of adjuvant imatinib for operable gastrointestinal stromal tumor: a randomized trial. JAMA. 2012;307(12):1265-72.

6. Demetri GD, van Oosterom AT, Garrett CR, Blackstein ME, Shah MH, Verweij J, McArthur G, Judson IR, Heinrich MC, Morgan JA, Desai J, Fletcher CD, George S, Bello CL, Huang X, Baum CM, Casali PG. Efficacy and safety of sunitinib in patients with advanced gastrointestinal stromal tumour after failure of imatinib: a randomised controlled trial. Lancet. 2006;368(9544): 1329-38.

7. Demetri GD, Reichardt P, Kang YK, Blay JY, Rutkowski P, Gelderblom H, Hohenberger P, Leahy M, von Mehren M, Joensuu H, Badalamenti G, Blackstein M, Le Cesne A, Schöffski P, Maki RG, Bauer S, Nguyen BB, Xu J, Nishida T, Chung J, Kappeler C, Kuss I, Laurent D, Casali PG, GRID study investigators. Efficacy and safety of regorafenib for advanced gastrointestinal stromal tumours after failure of imatinib and sunitinib (GRID): an international, multicentre, randomised, placebo-controlled, phase 3 trial. Lancet. 2013;381(9863):295-302.

8. Therasse P, Arbuck SG, Eisenhauer EA, Wanders J, Kaplan RS, Rubinstein L, Verweij J, Van Glabbeke M, van Oosterom AT, Christian MC, Gwyther SG. New guidelines to evaluate the response to treatment in solid tumors. J Natl Cancer Inst. 2000; 92:205-16.

9. Choi H, Charnsangavej C, Faria SC, Macapinlac HA, Burgess MA, Patel SR, Chen LL, Podoloff DA, Benjamin RS. Correlation of computed tomography and positron emission tomography in patients with metastatic gastrointestinal stromal tumor treated at a single institution with imatinib mesylate: proposal of new computed tomography response criteria. J Clin Oncol. 2007;25(13): 1753-9.

10. Rutkowski P, Nowecki ZI, Nyckowski P, Dziewirski W, Grzesiakowska U, Nasierowska-Guttmejer A, Krawczyk M, Ruka W. Surgical treatment of patients with initially inoperable and/or metastatic gastrointestinal stromal tumors (GIST) during therapy with imatinib mesylate. J Surg Oncol. 2006;4:304-11.

11. Wozniak A, Rutkowski P, Piskorz A, Ciwoniuk M, Osuch C, Bylina E, Sygut J, Chosia M, Rys J, Urbanczyk K, Kruszewski W, Sowa P, Siedlecki J, Debiec-Rychter M, Limon J, on behalf of Polish Clinical GIST Registry. Prognostic value of KIT/PDGFRA mutations in gastrointestinal stromal tumors (GIST): Polish Clinical GIST Registry experience. Ann Oncol. 2012;23(2): 353-60.

12. Blanke CD, Rankin C, Demetri GD, Ryan CW, von Mehren M, Benjamin RS, Raymond AK, Bramwell VH, Baker LH, Maki RG, Tanaka M, Hecht JR, Heinrich MC, Fletcher CD, Crowley JJ, Borden EC. Phase III randomized, intergroup trial assessing imatinib mesylate at two dose levels in patients with unresectable or metastatic gastrointestinal stromal tumors expressing the kit receptor tyrosine kinase: S0033. J Clin Oncol. 2008;26(4): 626-32.

13. Blanke CD, Demetri GD, von Mehren M, Heinrich MC, Eisenberg B, Fletcher JA, Corless CL, Fletcher CD, Roberts PJ, Heinz D, Wehre E, Nikolova Z, Joensuu H. Long-term results from a randomized phase II trial of standard- versus higher-dose imatinib mesylate for patients with unresectable or metastatic gastrointestinal stromal tumors expressing KIT. J Clin Oncol. 2009; 27(24):3969-74.

14. Gold JS, van der Zwan SM, Gönen M, Maki RG, Singer S, Brennan MF, Antonescu CR, De Matteo RP. Outcome of metastatic GIST in the era before tyrosine kinase inhibitors. Ann Surg Oncol. 2007;14(1):134-42.

15. Patel S. Long-term efficacy of imatinib for treatment of metastatic GIST. Cancer Chemother Pharmacol. 2013;72(2):277-86.

16. Call J, Walentas CD, Eickhoff JC, Scherzer N. Survival of gastrointestinal stromal tumor patients in the imatinib era: life raft group observational registry. BMC Cancer. 2012;12:90.

17. Gastrointestinal Stromal Tumor Meta-Analysis Group (MetaGIST). Comparison of two doses of imatinib for the treatment of unresectable or metastatic gastrointestinal stromal tumors: a meta-analysis of 1,640 patients. J Clin Oncol. 2010;28(7):1247-53.

18. Ryu MH, Kang WK, Bang YJ, Lee KH, Shin DB, Ryoo BY, Roh JK, Kang JH, Lee H, Kim TW, Chang HM, Park JO, Park YS, Kim TY, Kim MK, Lee WK, Kang HJ, Kang YK. A prospective, multicenter, phase 2 study of imatinib mesylate in Korean patients with metastatic or unresectable gastrointestinal stromal tumor. Oncology. 2009;76:326-32.

19. Saito S, Nakata K, Kajiura S, Ando T, Hosokawa A, Sugiyama T. Long-term follow-up outcome of imatinib mesylate treatment for recurrent and unresectable gastrointestinal stromal tumors. Digestion. 2013;87(1):47-52.

20. Yeh CN, Chen YY, Tseng JH, Chen JS, Chen TW, Tsai CY, Cheng CT, Jan YY, Chen MF. Imatinib mesylate for patients with recurrent or metastatic gastrointestinal stromal tumors expressing KIT: a decade experience from Taiwan. Transl Oncol. 2011;4(6):328-35.

21. Zhu J, Yang Y, Zhou L, Jiang M, Hou M. A long-term follow-up of the imatinib mesylate treatment for the patients with recurrent gastrointestinal stromal tumor (GIST): the liver metastasis and the outcome. BMC Cancer. 2010;10:199.

22. Blanke CD, Rankin $\mathrm{C}$, Benjamin $\mathrm{R}$, et al. Long-term survival on S0033-a phase III randomized, intergroup trial assessing imatinib mesylate at two dose levels in patients with unresectable or metastatic gastrointestinal stromal tumours (GISTs). Eur J Cancer. 2011;47(Suppl 1):(Abstr 9404).

23. Blesius A, Cassier PA, Ray-Coquard IL, et al. Who are the long responders to imatinib (IM) in patients with advanced GIST? Results of the BFR14 prospective French Sarcoma Group randomized phase III trial. J Clin Oncol. 2011;29:(Abstr 10048).

24. Byrd DM, Demetri GD, Joensuu H, et al. Evaluation of imatinib mesylate in patients with large volume gastrointestinal stromal tumors. J Clin Oncol. 2007;25:558s(Abstr).

25. von Mehren $\mathrm{MCH}$, Joensuu $\mathrm{H}$, Blanke $\mathrm{CD}$, et al. Follow-up results after 9 years (yrs) of the ongoing, phase II B2222 trial of imatinib mesylate (IM) in patients (pts) with metastatic or unresectable kit+ gastrointestinal stromal tumors (GIST). J Clin Oncol. 2011;29(suppl):(Abstr 10016).

26. Rutkowski P, Nowecki ZI, Debiec-Rychter M, Grzesiakowska U, Michej W, Woźniak A, Siedlecki JA, Limon J, vel Dobosz AJ, Kakol M, Osuch C, Ruka W. Predictive factors for long-term effects of imatinib therapy in patients with inoperable/metastatic CD117(+) gastrointestinal stromal tumors (GISTs). J Cancer Res Clin Oncol. 2007;133(9):589-97.

27. Van Glabbeke M, Verweij J, Casali PG, Le Cesne A, Hohenberger P, Ray-Coquard I, Schlemmer M, van Oosterom AT, Goldstein D, Sciot R, Hogendoorn PC, Brown M, Bertulli R, Judson IR. Initial and late resistance to imatinib in advanced gastrointestinal stromal tumors are predicted by different prognostic factors: a European Organisation for Research and Treatment of Cancer-Italian Sarcoma Group-Australasian Gastrointestinal Trials Group study. J Clin Oncol. 2005;23(24):5795-804.

28. Goldstein D, Lee C, Hui Y, Shah B, Yip D, McArthur GA. Development of a nomogram to predict overall survival in patients with locally advanced or metastatic gastrointestinal 
stromal tumor receiving first-line treatment with imatinib. J Clin Oncol. 2010;28(Suppl):15s(Abstr 10054).

29. Judson I, Ma P, Peng B, Verweij J, Racine A, di Paola ED, van Glabbeke M, Dimitrijevic S, Scurr M, Dumez H, van Oosterom A. Imatinib pharmacokinetics in patients with gastrointestinal stromal tumour: a retrospective population pharmacokinetic study over time. EORTC Soft Tissue and Bone Sarcoma Group. Cancer Chemother Pharmacol. 2005;55(4):379-86.

30. Yoo C, Ryu MH, Ryoo BY, Beck MY, Chang HM, Lee JL, Kim TW, Kang YK. Changes in imatinib plasma trough level during long-term treatment of patients with advanced gastrointestinal stromal tumors: correlation between changes in covariates and imatinib exposure. Invest New Drugs. 2012;30(4):1703-8.

31. Chen P, Zong L, Zhao W, Shi L. Efficacy evaluation of imatinib treatment in patients with gastrointestinal stromal tumors: a metaanalysis. World J Gastroenterol. 2010;16(33):4227-32.

32. Debiec-Rychter M, Sciot R, Le Cesne A, Schlemmer M, Hohenberger P, van Oosterom AT, Blay JY, Leyvraz S, Stul M, Casali PG, Zalcberg J, Verweij J, Van Glabbeke M, Haqemeijer A, Judson I. EORTC Soft Tissue and Bone Sarcoma Group, Australasian Gastrointestinal Trial Group. KIT mutations and dose selection for imatinib in patients with advanced gastrointestinal stromal tumours. Eur J Cancer. 2006;2(8):1093-103.

33. Heinrich MC, Corless CL, Demetri GD, Blanke CD, von Mehren M, Joensuu H, McGreevey LS, Chen CJ, van den Abbeele AD, Druker BJ, Kiese B, Eisenberg B, Roberts PJ, Singer S, Fletcher CD, Silberman S, Dimitrijevic S, Fletcher JA. Kinase mutations and imatinib response in patients with metastatic gastrointestinal stromal tumor. J Clin Oncol. 2003;21(23):4342-9.

34. Heinrich MC, Owzar K, Corless CL, Hollis D, Borden ED, Fletcher CDM, Ryan CW, von Mehren M, Blanke CD, Rankin C, Benjamin RS, Bramwell VH, Demetri GD, Bertagnolli MM, Fletcher JA. Correlation of kinase genotype and clinical outcome in the North American Intergroup Phase III Trial of imatinib mesylate for treatment of advanced gastrointestinal stromal tumor: CALGB 150105 Study by Cancer and Leukemia Group B and Southwest Oncology Group. J Clin Oncol. 2008;26:5360-7.

35. Rutkowski P, Bylina E, Klimczak A, Switaj T, Falkowski S, Kroc J, Lugowska I, Brzeskwiniewicz M, Melerowicz W, Osuch C, Mierzejewska E, Wasielewski K, Woźniak A, Grzesiakowska U, Nowecki ZI, Siedlecki JA, Limon J. The outcome and predictive factors of sunitinib therapy in advanced gastrointestinal stromal tumors (GIST) after imatinib failure-one institution study. BMC Cancer. 2012;12:107.

36. Debiec-Rychter M, Dumez H, Judson I, Wasag B, Verweij J, Brown M, Dimitrijevic S, Sciot R, Stul M, Vranck H, Scurr M, Hagemeijer A, van Glabbeke M, van Oosterom AT. EORTC Soft Tissue and Bone Sarcoma Group. Use of c-KIT/PDGFRA mutational analysis to predict the clinical response to imatinib in patients with advanced gastrointestinal stromal tumours entered on phase I and II studies of the EORTC Soft Tissue and Bone Sarcoma Group. Eur J Cancer. 2004;40(5):689-95.

37. Rutkowski P, Wozniak A, Debiec-Rychter M, Kakol M, Dziewirski W, Zdzienicki M, Ptaszynski K, Jurkowska M, Limon J,
Siedlecki JA. Clinical utility of the new American Joint Committee on Cancer staging system for gastrointestinal stromal tumors: current overall survival after primary tumor resection. Cancer. 2011;117(21):4916-24.

38. Debiec-Rychter M, Cools J, Dumez H, Sciot R, Stul M, Mentens N, Vranckx H, Wasag B, Prenen H, Roesel J, Hagemeijer A, van Oosterom A, Marynen P. Mechanisms of resistance to imatinib mesylate in gastrointestinal stromal tumors and activity of the PKC412 inhibitor against imatinib-resistant mutants. Gastroenterology. 2005;128(2):270-9.

39. Andtbacka RHI, Ng CS, Scaife CL, Cormier JN, Hunt KK, Pisters PW, Pollock RE, Benjamin RS, Burgess MA, Chen LL, Trent J, Patel SR, Raymond K, Feig BW. Surgical resection of gastrointestinal stromal tumors after treatment with imatinib. Ann Surg Oncol. 2007;14(1):14-21.

40. Gronchi A, Fiore M, Miselli F, Lagonigro MS, Coco P, Messina A, Pilotti S, Casali PG. Surgery of residual disease following molecular-targeted therapy with imatinib mesylate in advanced/ metastatic GIST. Ann Surg. 2007;245(3):353-64.

41. Raut CP, Posner M, Desai J, Morgan JA, George S, Zahrieh D, Fletcher CD, Demetri GD, Bertagnolli MM. Surgical management of advanced gastrointestinal stromal tumors after treatment with targeted systemic therapy using kinase inhibitors. J Clin Oncol. 2006;24:2325-31.

42. Tielen R, Verhoef C, van Coevorden F, Gelderblom H, Sleijfer S, Hartgrink HH, Bonenkamp JJ, van der Graaf WT, de Wilt JH. Surgery after treatment with imatinib and/or sunitinib in patients with metastasized gastrointestinal stromal tumors: is it worthwhile? World J Surg Oncol. 2012;10:111.

43. Gronchi A, Raut CP. The combination of surgery and imatinib in GIST: a reality for localized tumors at high risk, an open issue for metastatic ones. Ann Surg Oncol. 2012;19(4):1051-5.

44. Zalcberg JR, Verweij J, Casali PG, Le Cesne A, Reichardt P, Blay JY, Schlemmer M, Van Glabbeke M, Brown M, Judson IR, EORTC Soft Tissue and Bone Sarcoma Group, the Italian Sarcoma Group, Australasian Gastrointestinal Trials Group. Outcome of patients with advanced gastro-intestinal stromal tumours crossing over to a daily imatinib dose of $800 \mathrm{mg}$ after progression $400 \mathrm{mg}$. Eur J Cancer. 2005;41(12):1751-7.

45. Montemurro M, Gelderblom H, Bitz U, Schütte J, Blay JY, Joensuu H, Trent J, Bauer S, Rutkowski P, Duffaud F, Pink D. Sorafenib as third- or fourth-line treatment of advanced gastrointestinal stromal tumour and pretreatment including both imatinib and sunitinib, and nilotinib: a retrospective analysis. Eur J Cancer. 2012;49(5):1027-31.

46. Italiano A, Cioffi A, Coco P, Maki RG, Schöffski P, Rutkowski P, Le Cesne A, Duffaud F, Adenis A, Isambert N, Bompas E, Blay JY, Casali P, Keohan ML, Toulmonde M, Antonescu CR, Debiec-Rychter M, Coindre JM, Bui B. Patterns of care, prognosis, and survival in patients with metastatic gastrointestinal stromal tumors (GIST) refractory to first-line imatinib and second-line sunitinib. Ann Surg Oncol. 2012;19(5):1551-9. 